\title{
Minimal inhibitory concentration (MIC) determination of disinfectant and/or sterilizing agents
}

\author{
Priscila Gava Mazzola ${ }^{1, *}$, Angela Faustino Jozala², Letícia Célia de Lencastre Novaes², Patricia \\ Moriel $^{1}$, Thereza Christina Vessoni Penna ${ }^{2}$
}

\begin{abstract}
${ }^{1}$ Department of Clinical Pathology, Faculty of Medical Sciences, State University of Campinas, ${ }^{2}$ Department of BiochemicalPharmaceutical Technology, Faculty of Pharmaceutical Sciences, University of São Paulo
\end{abstract}

\begin{abstract}
Due to the growing number of outbreaks of infection in hospital and nurseries, it becomes essential to set up a sanitation program that indicates that the appropriate chemical agent was chosen for application in the most effective way. Validating the effectiveness of decontamination and disinfection is an important and often challenging task. In order to study and compare the behavior of selected microorganisms, they were submitted to minimal inhibitory concentration (MIC). The MIC intervals, which reduced bacteria populations over $6 \log 10$, were: 59 to $156 \mathrm{mg} / \mathrm{L}$ of quaternary ammonium compounds (QACs); 63 to $10000 \mathrm{mg} / \mathrm{L}$ of chlorhexidine; 1375 to $3250 \mathrm{mg} / \mathrm{L}$ of glutaraldehyde; 39 to $246 \mathrm{mg} / \mathrm{L}$ of formaldehyde; 43750 to $87500 \mathrm{mg} / \mathrm{L}$ of ethanol; 1250 to $6250 \mathrm{mg} / \mathrm{L}$ of iodine in polyvinyl-pyrolidone complexes, 150 to $4491 \mathrm{mg} / \mathrm{L}$ of chlorine-releasing-agents (CRAs) and 469 to $2500 \mathrm{mg} / \mathrm{L}$ of hydrogen peroxide. Chlorhexidine showed non inhibitory activity over germinating spores. A. calcoaceticus showed resistance to the majority of the agents tested, followed by E. cloacae and S. marcescens.
\end{abstract}

Uniterms: Minimal inhibitory concentration. Disinfectant agents. Sterilizing agents. Sanitation/ programs.

Devido ao número crescente de surtos de infecção hospitalar, torna-se proeminente o estabelecimento de um programa de sanitização que liste os agentes químicos a serem empregados e o modo de aplicação mais efetivo. Validação da eficácia de descontaminação é uma tarefa ao mesmo tempo importante e desafiadora. Para estudar e comparar o comportamento dos microrganismos selecionados foram realizados ensaios de concentração inibitória mínima (CIM). A CIM capaz de reduzir o bioburden inicial (>6 log 10) foi: 59 - $156 \mathrm{mg} / \mathrm{L}$ de quartenários de amônia; $63-10000 \mathrm{mg} / \mathrm{L}$ de clorexidina, $1375-3250 \mathrm{mg} / \mathrm{mL}$ de glutaraldeído, 39 - $246 \mathrm{mg} / \mathrm{L}$ de formaldeído, 43750 - $87500 \mathrm{mg} / \mathrm{L}$ de etanol 1250 - $6250 \mathrm{mg} / \mathrm{L}$ de PVPI, 150 - $4491 \mathrm{mg} / \mathrm{L}$ de compostos liberadores de cloro e 469 -2500 mg/L de peróxido de hidrogênio.

Unitermos: Concentração inibitória mínima. Agentes desinfetantes. Agentes esterilizantes. Sanitização/ programas.

\section{INTRODUCTION}

The first pass for election of a sanitizing/sterilizing agent is the determination of its finality and type of area, material or surface to be submitted to treatment (Mazzola, 2000). It is necessary that some terms are clearly defined (Rutala, Weber, 1998, 2004):

(i) cleanness - it is the procedure of removal of dirtiness and detracts to maintain in a tidiness status the goo-

\footnotetext{
Correspondence: P. G. Mazzola. Departamento de Patologia Clínica, Faculdade de Ciências Médicas, Universidade Estadual de Campinas. Rua Tessália Vieira de Camargo, 126 - 13081-970 Campinas, SP, Brazil. E-mail: pmazzola@usp.br
}

ds, reducing the microbial population. The cleanness should precede all procedures of disinfection and sterilization, because it decreases the microbial load through the removal of present organic material. The washing with water and soap reduces considerably the initial bioburden. The presence of organic material alters parameters of the disinfection and sterilization procedures, besides to slow down them (Rutala, 1995, 1996, 1998).

(ii) decontamination - it has a objective to decrease the microorganisms load present in goods, becoming them safe for handling, decreasing the occupational risk. In this process, there is no necessity of employ- 
ment of disinfecting chemical substances, because the majority of these solutions have great affinity for organic molecules, and do not reach directly the contaminating microorganism (Rutala, 1995; 1996; 1998).

(iii) disinfection - removal of microorganisms in the vegetative form, irrespective of their pathogenic character, from inanimate goods and surfaces; with possible removal of sporulated bacteria. The disinfection could be classified into three categories: (1) high level disinfection (should include the elimination of vegetative bacteria, tuberculosis bacilli, fungi, viruses and some bacterial spores, being indicated for semi-critical items); (2) disinfection of middle or intermediate level (indicated for non-critical goods and surfaces, it involves the elimination of the majority of fungi, all vegetative bacterial cells and tuberculosis bacilli; however, it is not expected an action on bacterial spores), (3) low level disinfection (indicated for goods that will be in contact only with whole skin or for disinfection of surfaces, there is no action on the tuberculosis spores or bacilli, relative activity on fungi, able to eliminate bacteria in vegetative form) (Rutala, 1995; 1996; 1998).

(iv) sterilization - it is a process promoting complete elimination or destruction of all forms of microorganism that could be developed during the shelf life cycle of the considered item. Conventionally, a good is considered sterile when the probability of survival of a microorganism is lower than 1:1.000.000 $\left(10^{-6}\right)$. To process of sterilization could be physical (saturated vapor/autoclaves, dry warmth, gamma rays/ cobalt), chemical (glutaraldehyde, formaldehyde, peracetic acid), and physicochemical (ethylene oxide-ETO, hydrogen peroxide plasma, gases plasma, and formaldehyde vapor stabilizers) (Rutala, 1995; 1996; 1998).

In order to differentiate cleaning and sanitization processes, the areas are classified and subdivided, according the potential risk of infections acquisition in: critical, semi-critical and non-critical. Due to its particularities, the surgical center has its own and differentiated cleaning techniques (Brasil, 2001).

(i) critical areas - they offer potential risk for patient acquisition of infections due to developed procedures or handling of infective materials.

(ii) semi-critical areas - all those that do not require intensive care or isolation. For instance: outpatients unit, radiology, ultrasonography, and infirmary.

(iii) non-critical areas - are all hospital areas not occupied by patients.
The materials that are utilized in health establishments could also be classified, according their potential risk of infection transmission to patients, into three categories (Brasil, 2001):

(i) critical goods - destined to invasive procedures to be developed in the skin, adjacent mucous membranes, subepithelial tissues and the vascular system, as well as all others that are directly connected with this system. These materials require sterilization to satisfy the proposed objectives. Needles, invasive catheters, implantation materials are some examples.

(ii) semi-critical goods - goods entering in contact with disrupted skin or whole mucous membranes require high or intermediate level disinfection, and in some more specific cases, sterilization. Endotracheal cannula, vaginal speculum, respiratory equipment are some examples.

(iii) non-critical goods - destined to contact with whole skin or those that do not enter in contact with patient, require low level cleaning or disinfection. Thermometers, stethoscope, bed linen, are some examples that are part of this group.

There are factors that alter the efficacy of disinfection and sterilization procedures. The antimicrobial activity of chemical agents depends on a variety of factors related to nature, structure and conditions of microorganisms, and chemical and physical components of the external environment. The knowledge of these factors is indispensable for an adequate application of disinfection and sterilization processes. The non-observance of these factors could imply in the failure of these procedures (Mazzola, 2000).

Despite the great offer of chemical products in the market, the choice of the more adequate one is not an easy task. Several characteristics should be considered: their spectrum of action, velocity of microorganisms inactivation, non-corrosive condition for metals, do not be harmful to rubber accessories, plastics or optical equipment, do not be inactivated by the presence of organic material, tolerance to small $\mathrm{pH}$ variations, to have residual action when applied to environments, to maintain its action even in mild dilutions, to be odorless, non-poisonous and stable (even if concentrated or diluted) (Brasil, 1988).

\section{Regulation of disinfectants in Brazil}

In Brazilian legislation, disinfectant solutions adequate for use and those prohibited for disinfection are named. Between the minimal conditions required for the regular status of a disinfectant agent are: germicide activity in the cutaneous flora, without cause irritation 
to skin or mucous membranes; do not cause allergic reactions or burning, and present a low level of toxicity (Brasil, 1994).

The chemical disinfectant and sterilizing agents pertain to a class named sanitizing agents with antimicrobial action. Such products are subjected to health surveillance regimen according to Laws 6360/76 and 6437/77. The ordinance number 15, of 1988 (Brasil, 1988), regulates the chemical agents whose active principles are allowed. Between them, are: the aldehydes, phenolics, quaternary ammonium, organic compounds releasers of active chloride, iodine and derivatives, alcohols and glycols, biguanides. Are mentioned yet in this Ordinance, definitions, classification, specific and labeling requests as well as microorganisms, face to which the sanitizing agents should present activity and toxicological classification.

Respecting to quality control of sterilizing chemical agents, the National Institute of Health Control of Oswaldo Cruz Foundation (Instituto Nacional de Controle em Saúde da Fundação Oswaldo Cruz - INCQS/FIOCRUZ) is the organ of national reference for technological and normative issues referring to supplies, products, environment and services linked to Health Surveillance. In the area of sanitizing agents, the INCQS develops laboratory analysis for microbial verification, chemical and toxicological evaluation to attend to current legal requirements, and in the systematic programs of evaluation of products quality.

\section{Disinfectants Efficiency}

Due to growing number of hospital infection cases, it becomes of extreme importance to establish programs of sanitizing implying in the choice of adequate disinfectant agents, as well as their effective application (Penna et al., 2001).

In order to decrease costs and human failures in the preparation and utilization of sanitizing solutions, it is necessary to standardize a minimum of chemical products presenting proven efficacy, define their indicated concentration and dilution, and the finality to which they are destined (Rutala, 1995; 1996; 1998).

Due to growing number of hospital infection outbreaks, it becomes prominent the establishment of a sanitizing program listing the chemical agents to be employed and their more effective mode of application. Validation of decontaminating efficacy is a task, at the same time, important and challenger. To study and compare the behavior of selected microorganisms, minimum inhibitory concentration (MIC) assays were developed. This present work intended to evaluate the efficacy of hospital use sanitizing agents, through the determination of minimum inhibitory concentration (MIC). The tested microbial strains were: Bacillus subtilis var. globigii ATCC 9372, Bacillus stearothermophilus ATCC 7953, Escherichia coli ATCC 25922, Staphylococcus aureus ATCC 25923, Enterobacter cloacae IAL 1976 (registration of Adolfo Lutz Institute), Serratia marcescens IAL 1478 (registration of Adolfo Lutz Institute) and Acinetobacter calcoaceticus ATCC 19606, IAL 124 (registration of Adolfo Lutz Institute). Through the MIC determination and activity spectrum classification of every sterilizing agent, it becomes possible to outline a cleaning, disinfection and sterilization program in the hospital environment, mainly of reusable materials.

\section{MATERIAL AND METHODS}

\section{Material}

The tested microorganisms were acquired from ATCC (American Type Culture Collection) or Adolfo Lutz Institute (Instituto Adolfo Lutz - IAL). Culture mediums, peracetic acid, iodine, hydrogen peroxide and remaining reagents were acquired from Sigma (St. Louis, MO). The tested chemical agents, chlorhexidine gluconate, quaternary ammonium compounds, glutaraldehyde, formaldehyde, ethylic alcohol, ethanol plus glycerin solution, topical Polyvidine ${ }^{\circledR}$ (Polyvinylpyrrolidone - PVPI), Polyvidine soap ${ }^{\circledR}$ (PVPI), Polyvidine in aqueous solution ${ }^{\circledR}$ (PVPI) were kindle provided by Aster Produtos Médicos Ltda. (Sorocaba, SP), sodium dichloroisocyanurate (NaDCC) was kindle provided by Johnson \& Johnson, chlorinereleasing agents (CRA's) were prepared from concentrated commercial solution of sodium hypochlorite, the concentration of free chlorine, hydrogen peroxide and iodine were determined by iodometric method (Baccan et al., 1985).

\section{Methods}

\section{Inoculation preparation}

The stock cultures were maintained in trypticase soy agar (TSA, Difco, Detroit, MI, USA) at $4{ }^{\circ} \mathrm{C}$, and weekly transferences were developed with the purpose to maintain the viability of microorganisms.

The cultures were started from the transference of stock cultures for trypticase soy broth (TSB, Difco, Detroit, MI, USA) at $22^{\circ} \mathrm{C}$ for $S$. marcencens, and at 35$37^{\circ} \mathrm{C}$ for E. cloacae, A. calcoaceticus, E. coli, S. aureus, for a period of 24 hours. After growth, the samples were centrifuged $\left(1000 \mathrm{~g} / 15 \mathrm{~min} / 4{ }^{\circ} \mathrm{C}\right)$ and resuspended in saline solution. The viability of bacteria was estimated through the Pour-Plate technique utilizing the TSA me- 
dium, confirming populations in concentrations higher than $10^{7} \mathrm{CFU} / \mathrm{mL}$.

The cultures of spores were developed in sporulation medium, after 6 days of culture at $37^{\circ} \mathrm{C}$ for $B$. subtilis, and at $62{ }^{\circ} \mathrm{C}$ for $B$. stearothermophilus; the cultures were transferred, centrifuged (1935 g for $30 \mathrm{~min}$ ) and the suspension was maintained at low temperature in solution of calcium acetate $(\mathrm{pH}=9.7)$, at $4{ }^{\circ} \mathrm{C}$, to maintain their viability (Penna et al., 1998). To assure the viability of sporulated forms, and inactivate the vegetative forms, the samples were submitted to thermal chock treatment $\left(80^{\circ} \mathrm{C} / 10 \mathrm{~min}\right.$ for B. subtilis and $100^{\circ} \mathrm{C} / 20 \mathrm{~min}$ for $B$. stearothermophilus); after the periods determined for culture, the number of spores was determined through TSA in depth culture, confirming population in concentration higher than $10^{6}$ spores $/ \mathrm{mL}$.

\section{Minimum Inhibitory Concentration (MIC) Determination}

This assay consists in the determination of chemical agent spectrum of action, according to resistance of studied microorganisms. It was developed the determination of minimum inhibitory concentration (MIC) for every chemical agent, through the classic method of successive dilution. In twelve numbered screw tubes $(10 \times 100 \mathrm{~mm})$, $1 \mathrm{~mL}$ of TSB (trypticase soy broth) medium was distributed for every tube, except for the tube number 1 . The tubes were submitted to autoclave under constant pressure and temperature of $121^{\circ} \mathrm{C}$. For the first and the second tubes of the series, $1 \mathrm{~mL}$ of tested sanitizing agent was added; tube 2 was stirred and $1 \mathrm{~mL}$ was withdrawn and transferred for tube 3 . This successive transference was repeated until tube 11. It was added to all flasks, except for flask number
$11,0.1 \mathrm{~mL}$ of inoculation (tested microorganism) at known concentration. Incubation at optimal temperature was developed for 24 and 48 hours (Figure 1). After this period, the reading was developed; the MIC is the concentration of the higher dilution tube in which the absence of bacterial growth occurred. Tubes 11 and 12 are positive (TSB + inoculation) and negative (TSB + antimicrobial) controls (Mazzola et al., 2001, 2003).

\section{RESULTS AND DISCUSSION}

The investigated chemical agents are extensively utilized in commercial solutions by health centers and hospital environments, as for topic use as for surfaces. The data collected are presented in Table I.

Quaternary ammonium compounds (QACs) - they do not present sporocide activity, their activity inhibits the growth of microorganisms and the spores germination (McDonnell, Russell, 1998). Minimum inhibitory concentration values of 117 and $156 \mathrm{mg} / \mathrm{L}$ were determined for $B$. subtilis and B. stearothermophilus, and correspond to two times the MIC values for vegetative cells of $E$. cloacae, E. coli, S. aureus and S. marcescens (MIC between $59-78 \mathrm{mg} / \mathrm{L}$ ). The more sensible microorganism was $A$. calcoaceticus $(9.77 \mathrm{mg} / \mathrm{L})$. In health centers, the QACs are considered low level disinfectants, and generally they are employed in concentrations of $2000 \mathrm{mg} / \mathrm{L}$, without formaldehyde in the formulation (Brasil, 1988) the QACs are extensively utilized as antiseptics, do to their nonaggressive action, and in surfaces because they present residual activity and could act replacing phenolic com-

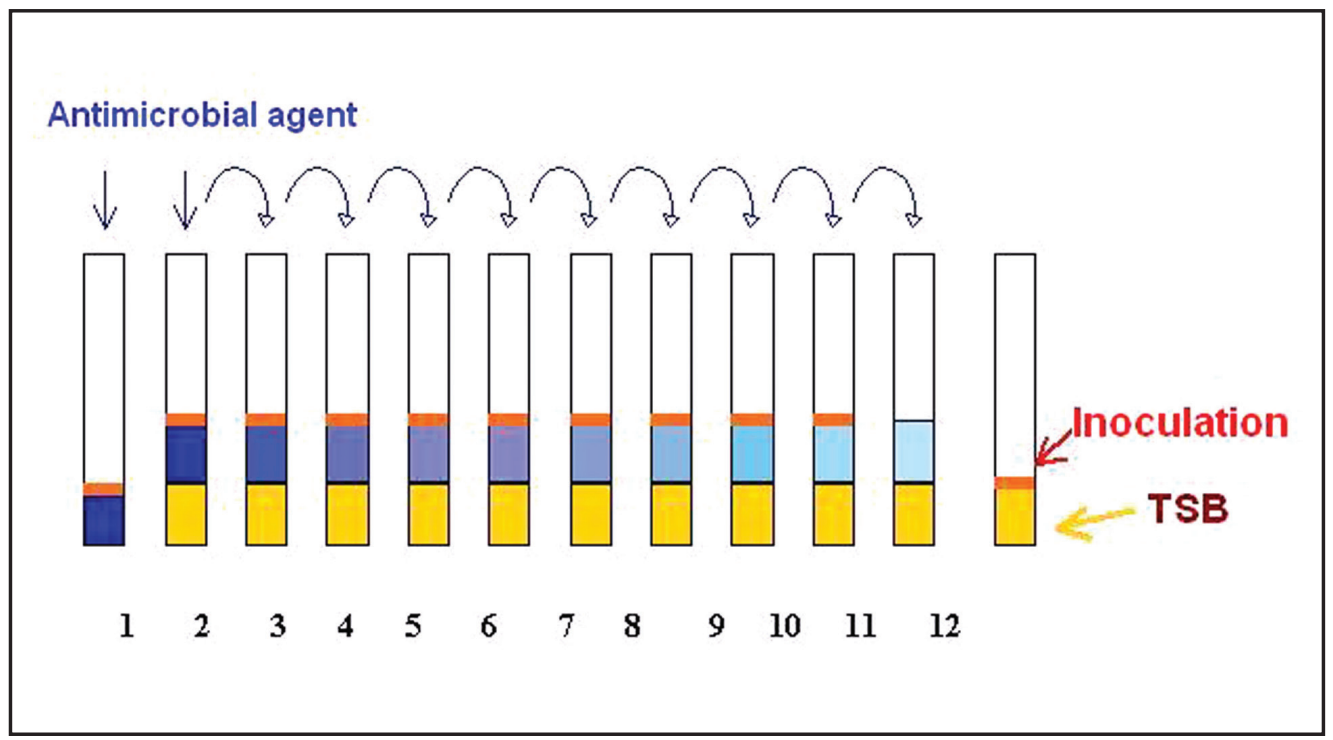

FIGURE 1 - Illustrative scheme of successive dilutions method. 
pounds, which are more toxic. In baby nurseries, the QACs should be utilized in the cleaning of cradles, counters and other surfaces, minimizing cross-contamination and the risks of microorganisms superpopulation.

Chlorhexidine digluconate - in Brazilian hospitals, solutions of $4 \%$ chlorhexidine are employed for hands washing by the employees. In this study, chlorhexidine was effective face to B. subtilis (MIC $10000 \mathrm{mg} / \mathrm{L}$ ), but did not present efficacy when tested face to $B$. stearothermophilus. The concentration interval of $63-71 \mathrm{mg} / \mathrm{L}$ demonstrated to be effective when tested face to E. cloacae, E. coli and $S$. aureus; the bacterium $S$. marcescens presented higher resistance, with MIC of $141 \mathrm{mg} / \mathrm{L}$. Chlorhexidine (4\%) in alcoholic solution (4\%) are commonly employed for washing hands of clinical staff and employees, as well as in the pre-surgical asepsis. The alcohol added in the formulation prevents cross contamination with $B$. proteus and Pseudomonas (Brasil, 1988). Alcoholic solution of chlorhexidine $0.5 \%$ is indicated as topical antiseptic, replacing PVPI. In lower concentrations $(0.5 \%)$, the chlorhexidine is employed in the cleaning of contact lenses, being able to decrease populations of $S$. marcescens. Denton (1991) has studied the chlorhexidine $(30 \mathrm{mg} / \mathrm{L})$ in contact with $S$. marcescens for 10 minutes, and it showed similar efficacy to that of $500 \mathrm{mg} / \mathrm{L}$ solutions. However, Gandhi et al. (1993) demonstrated the ability of this strain to grow after 24 hours of contact with solutions up to $60 \mathrm{mg} / \mathrm{L}$.

Glutaraldehyde - it has bactericide, sporocide, fungicide and virucide effect; being also extensively employed for low level disinfections of critical and semicritical goods, the recommended exposition time is of 6-8 hours in $2 \%$ solution of glutaraldehyde (Brasil, 1999). The determined MIC results were $2750-3750 \mathrm{mg} / \mathrm{L}$ for B. subtilis, A. calcoaceticus, E. cloacae and E. coli, and $1375-1875 \mathrm{mg} / \mathrm{L}$ for $S$. marcescens, $S$. aureus and $B$. stearothermophilus. Despite the antimicrobial effect and cost-benefit relation, the side effects of glutaraldehyde demand a series of cautions and trainings before use (Rutala, Weber, 1995; 1998; 2004). It is also necessary to neutralize the product before discard it. After rinsing and removal of possible residues, glutaraldehyde does not represent a risk (Kenneth, 1994).

Formaldehyde - it presents as sporocide, virucide and fungicide activity, and could be employed also for environments fumigation. It was observed that after 8 hours of contact, $0.5-1 \%$ formaldehyde solutions caused a decrease of $6-9 \log _{10}$, in the average MIC of $58.5 \mathrm{mg} / \mathrm{L}$ for $S$. marcescens, $117 \mathrm{mg} / \mathrm{L}$ for E. cloacae, $156 \mathrm{mg} / \mathrm{L}$ for $S$. aureus and E. coli, $235 \mathrm{mg} / \mathrm{L}$ for B. subtilis and 246 $\mathrm{mg} / \mathrm{L}$ for $B$. stearothermophilus. The use of formaldehyde in Brazil is allowed for high level disinfection of critical and non-critical goods, such as dialyzer, filters, catheters, laparoscopes between others (Brasil, 1978; 2001). The recommendation is that such goods should be immersed in an $8 \%$ solution of formaldehyde using alcoholic solution as solvent, for 18 hours (such solution corresponds to $2 \%$ solution in water), followed by abundant washing (Brasil, 1988; 2001). In plants for production of parenteral solution that pass by a system of reverse osmosis, the osmosis membrane should be submitted to 18 hours of immersion in $1 \%$ formaldehyde solution, followed by abundant rinsing. Formaldehyde could even be administered as urinary antiseptic $(100-200 \mathrm{mg} / \mathrm{L}$ in the bladder) (Rutala, Weber, 1995; 1998, Kessler et al., 1988). The major disadvantages of formaldehyde are the loss of activity in presence of organic material and its carcinogenic potential (McDonnell, Russell, 1998, Rutala, Weber, 1998).

Ethanol-despite the ample antimicrobial activity, alcoholic solutions do not present sporocide activity; but, in specific cases, they could inhibit spores germination. To decrease populations of $6 \log _{10}$ of B. stearothermophilus, $B$. subtilis, $S$. aureus and E. cloacae it was necessary a MIC of $87500 \mathrm{mg} / \mathrm{L}$ and the bacterium $E$. coli presented a MIC of $65650 \mathrm{mg} / \mathrm{L}$. Some tested microorganisms presented higher sensibility, such as MIC of $43750 \mathrm{mg} / \mathrm{L}$ for $S$. marcescens and A. calcoaceticus. $70 \%$ alcoholic solutions are extensively utilized in the asepsis of hands, skin, goods and semi-critical environments, but they are not employed in routine cleanings, because they damage plastic, rubber and acrylic surfaces. The presence of glycerin (2\%), avoiding skin exsiccation by alcohol action, decreases the ethanol activity in some strains, except for E. cloacae and S. aureus, which maintained the MIC of $87500 \mathrm{mg} / \mathrm{L}$. The addition of iodine (1\% and 10\%) decreased the MIC for 43750 and $21870 \mathrm{mg} / \mathrm{L}$, when in contact with $E$. coli and $S$. aureus, respectively. The presence of $10 \%$ iodine decreased the MIC of ethanol to $43750 \mathrm{mg} / \mathrm{L}$ for B. subtilis and E. cloacae; and to $21870 \mathrm{mg} / \mathrm{L}$ for $S$. aureus. In Brazilian hospitals, solutions of $70 \%$ alcohol have replaced formaldehyde and phenol solutions for cleaning-disinfection of non-critical and semi-critical goods (Dias et al., 2000). Alcoholic solutions have also been added to other sanitizing agents such as chlorhexidine, formaldehyde and PVPI, in order to prevent the contamination with Gram-negative bacteria that are present in the hospital environment, and could be responsible by biofilms formation, impeding the penetration of disinfectant agents. The ethanol could also be employed as pre-surgical antiseptic in solutions with PVPI or chlorhexidine, presenting residual action (Brasil, 1988; 1999; 2001). Trautmann et al. (2001) observed that disinfection with alcohol before and after contact with patients has reduced the isolation of 
Gram-negative microorganisms. After washing hands, the asepsis with alcoholic solution represents the better alternative to avoid infections outbreaks in health centers, and also in environments of food handling. Conrad (2001) has verified an increase of, practically, almost two times in the consumption of alcoholic solution in a Swiss hospital, after rigorous control of cleaning and hands asepsis, decreasing the number of registered infections.

$P V P I$ - for aqueous solutions, the determined minimum inhibitory concentration was of $6250-12500$ $\mathrm{mg} / \mathrm{L}$; for alcoholic solutions, the MIC was of $1560 \mathrm{mg} / \mathrm{L}$ for $E$. coli to $12500 \mathrm{mg} / \mathrm{L}$ for $A$. calcoaceticus and $B$. stearothermophilus. The higher MIC found was for $B$. subtilis in both the solutions $(2.5-5.0 \%)$. The addition of $10 \%$ iodine to PVPI solution increases the antibacterial efficacy and decreases the cutaneous irritations; such solution is recommended for topical asepsis when added with non-ionic detergent (sodium lauryl ether sulfate). The alcoholic solution is utilized for delimitation of surgical field (Brasil, 1988).

Chlorine-releasing-agents (CRAs) - sodium hypochlorite $(\mathrm{NaOCl}, \mathrm{pH} 9.0)$ and sodium dichloroisocyanurate (NaDCC, pH 7.0) are extensively utilized for antisepsis and disinfection; they are also utilized for decontamination of non-critical surfaces exposed to blood (Rutala, Weber, 1998), despite their efficacy decrease in the presence of organic material. Similar MIC intervals were observed for the tested microorganisms, when taking into account the initial concentration of free chlorine varying between 8000-9000 $\mathrm{mg} / \mathrm{L}$. In 1\% CRA pH 9.0, the more resistant strain was $E$. coli, with a MIC around $1129 \mathrm{mg} / \mathrm{L}$; for strains able to form spores, the MIC was of $4491 \mathrm{mg} / \mathrm{L}$. The adjustment to 7.0 of $\mathrm{NaOCl}$ solution $\mathrm{pH}$ decreased the minimum inhibitory concentrations in ten times, due to $\mathrm{HOCl}$ predominance. The non-dissociated form of hypochlorous acid $(\mathrm{HClO})$ in water ( $\mathrm{pH} 4.0-7.0)$ is responsible for the antimicrobial activity of CRAs; and it is 100 times more effective as the dissociated form OCl- $(\mathrm{pH}>9.0)$ (Vessoni Penna et al., 1996; McDonnell \& Russell, 1999). Commercial solutions of chlorine should be buffered, favoring so the maintenance of $\mathrm{pH} 7.0$ and accelerating the formation of $\mathrm{HOCl}$. The MIC value was of $150 \mathrm{mg} / \mathrm{L}$ for vegetative cells and 621 $\mathrm{mg} / \mathrm{L}$ for strains able to form spores. Sodium hypochlorite is employed as base of disinfectants, presenting an ample spectrum of antimicrobial activity in varied temperatures. This compound is of easy access and handling, is not toxic and is compatible with detergents. The non-dissociated form, hypochlorous acid ( $\mathrm{HClO})$ in water $(\mathrm{pH} 4.0-7.0)$, is responsible for the antimicrobial activity of CRAs; and it is 100 times more effective as the dissociated form OCl- $(\mathrm{pH}$ >9.0) (Vessoni Penna et al., 1996; McDonnell \& Russell, 1998). Commercial solutions of chlorine should be buffered, favoring so the maintenance of $\mathrm{pH} 7.0$ and accelerating the formation of $\mathrm{HOCl}$.

Hydrogen peroxide - standard solution of $4 \%$ hydrogen peroxide $(40000 \mathrm{mg} / \mathrm{L})$ caused decrease of popula-

TABLE I - Minimum inhibitory concentration (MIC) of disinfecting chemical agents for strains tested face to microorganism suspensions $\left(>6 \log _{10}\right)$

\begin{tabular}{lccccccccccccccc}
\hline Bacteria & B. stearothermophilus & \multicolumn{2}{c}{ B. subtilis } & \multicolumn{2}{c}{ A.calcoaceticus } & \multicolumn{2}{c}{ E.cloacae } & \multicolumn{3}{c}{ E. coli } & \multicolumn{3}{c}{ S. marcescens } & \multicolumn{2}{c}{ S. aureus } \\
\hline MIC Chemical Ag. & $\mathrm{mg} / \mathrm{L}$ & $\%$ & $\mathrm{mg} / \mathrm{L}$ & $\%$ & $\mathrm{mg} / \mathrm{L}$ & $\%$ & $\mathrm{mg} / \mathrm{L}$ & $\%$ & $\mathrm{mg} / \mathrm{L}$ & $\%$ & $\mathrm{mg} / \mathrm{L}$ & $\%$ & $\mathrm{mg} / \mathrm{L}$ & $\%$ \\
\hline Quaternaries & 156 & 0.02 & 117 & 0.01 & 9.77 & 0.01 & 78 & 0.01 & 59 & 0.01 & 59 & 0.01 & 59 & 0.01 \\
Chlorhexidine & $*$ & $*$ & 10000 & 1.0 & 63 & 0.01 & 71 & 0.007 & 71 & 0.01 & 141 & 0.01 & 71 & 0.01 \\
Glutaraldehyde & 1875 & 0.19 & 3250 & 0.33 & 3250 & 0.33 & 3250 & 0.33 & 3250 & 0.33 & 1375 & 0.14 & 1875 & 0.19 \\
Formaldehyde & 246 & 0.03 & 235 & 0.02 & 39 & 0.01 & 117 & 0.01 & 156 & 0.02 & 58.5 & 0.01 & 156 & 0.02 \\
Ethanol & 87500 & 8.75 & 87500 & 8.75 & 43750 & 4.38 & 87500 & 8.75 & 65650 & 6.57 & 43750 & 4.38 & 87500 & 8.75 \\
Ethanol + Glycerin & $*$ & $*$ & $*$ & $*$ & 87500 & 8.75 & 87500 & 8.75 & 87500 & 8.75 & 87500 & 8.75 & 87500 & 8.75 \\
Ethanol + Iodine 1\% & 87500 & 8.75 & 87500 & 8.75 & 43750 & 4.38 & 87500 & 8.75 & 43750 & 4.38 & 43750 & 4.38 & 43750 & 4.38 \\
Ethanol + Iodine 10\% & $*$ & $*$ & 43750 & 4.38 & $*$ & $*$ & 43750 & 4.38 & $*$ & $*$ & $*$ & $*$ & 21870 & 2.19 \\
Topic Polvydine & (PVPI) & 12500 & 1.25 & 50000 & 5.0 & 12500 & 1.25 & 6250 & 0.63 & 12500 & 1.25 & 6250 & 0.63 & 6250 & 0.63 \\
Polvydine ${ }^{\circledR}$ - soap (PVPI) & 6250 & 0.63 & 50000 & 5.0 & 6250 & 0.63 & 6250 & 0.63 & 6250 & 0.63 & 6250 & 0.63 & 6250 & 0.63 \\
Alcoholic Polvydine & (PVPI) & 12500 & 1.25 & 25000 & 2.5 & 12500 & 1.25 & 3125 & 0.31 & 1560 & 0.16 & 3125 & 0.31 & 3125 & 0.31 \\
CRA 1\% pH 9 & 4491 & 0.45 & 4491 & 0.45 & 867 & 0.09 & 420 & 0.04 & 1129 & 0.11 & 474 & 0.05 & 945 & 0.09 \\
CRA 1 \% pH 7 & 621 & 0.06 & 621 & 0.06 & 150 & 0.02 & 150 & 0.02 & 150 & 0.02 & 150 & 0.02 & 150 & 0.02 \\
$\mathrm{H}_{2} \mathrm{O}_{2}$ & 1875 & 0.19 & 1875 & 0.19 & 469 & 0.05 & 1250 & 0.13 & 2505 & 0.25 & 625 & 0.06 & 938 & 0.09 \\
\hline
\end{tabular}

Legend: QAC- quaternary ammonium compounds, $\mathrm{H}_{2} \mathrm{O}_{2}$ - hydrogen peroxido; Alcohol - ethanol (EtOH) 70\%; EtOH + $\mathrm{I}_{2}-$ iodine in alcoholic solution; PVPI Polyvinylpyrrolidone iodine; CRA - chlorine-releasing-agents; NaDCC - sodium dichloroisocyanurate; * - without efficacy. 
tions higher than $8 \log _{10}$ and presented MIC of $1875 \mathrm{mg} / \mathrm{L}$ for B. subtilis and B. stearothermophilus. The remaining strains tested have presented lower resistance, with a MIC between 469 and $1250 \mathrm{mg} / \mathrm{L}$. Hydrogen peroxide is a strong oxidant agent, non-toxic and of easy handling, being extensively utilized in non-critical goods and surfaces. It is also employed in the treatment of effluents, food industry and other applications. Sagripanti and Bonifacino (1997) verified the sporocide effect of hydrogen peroxide solution in concentrations of $10 \%$, because the presence of organic material does not decreases its activity; lower concentrations have also demonstrated sporocide effect after a larger time of exposition.

\section{CONCLUSION}

The minimum inhibitory concentration method allows comparisons between the microorganisms exposed to the same chemical agents, but does not allow analog comparisons between the activities of different chemical agents. The presence of organic material in the assays, represented by culture medium (TSB), is recommended to increase the difficulty for the chemical agent to act on the microorganisms (Satar, 1998). The limitation of MIC determination assays is in the difficulty to know the culture medium effect on every singular used disinfectant.

MIC determines a range of disinfecting activity on a given group of selected microorganisms, suggesting which microorganism could be employed as biological indicator (BI) in every specific case. This method is also utilized to select the commercial chemical agent presenting the better performance, as compared with others. In order to evaluate the performance of every disinfectant it is important to study the time of decimal decreasing (D-value).

The chemical agent dilution until the bactericide concentration reaching should be realized with potable water, and the contact with dirtiness that could represent a gradual loss of activity for the chemical agent or even allow its transformation into a vehicle for microorganisms in the hospital environment, should be avoided. The chemical agents solutions should be maintained closed and protected from contamination sources.

Liquid disinfectants are employed all over the world due to their cost-benefit; in hospital environments the selected agent should be of easy handling, non-toxic and effective also in areas such as baby nurseries and other critical ones, avoiding cross contamination. The wrong use of disinfectant solutions could stimulate resistance in pathogenic microorganisms, and it is important reinforce that even the better programs of cleaning, disinfection and sterilization could promote infections, if not efficiently executed; whence the importance of trainings and implantation of control measures and periodic evaluation.

\section{ACKNOWLEDGES}

The authors recognize the funding from Foundation for Support to Research of the State of São Paulo (Fundação de Amparo à Pesquisa do Estado de São Paulo - FAPESP), the National Council of Scientific and Technologic Development (Conselho Nacional de Desenvolvimento Cientifico e Tecnológico- $\mathrm{CNPq}$ ) and the Coordination of Improvement of Higher Level Personnel (Coordenação de Aperfeiçoamento de Pessoal de Nivel Superior-CAPES).

\section{REFERENCES}

BACCAN, N.; ANDRADE, J. C.; GODINHO, O. E. S.; BARONE, J. S. Química analítica quantitativa elementar. São Paulo: Edgard Blücher, 1985. 308 p.

BRASIL. Ministério da Saúde. Coordenação de Controle de Infecção Hospitalar. Processamento de artigos e superficies em estabelecimentos de saúde. 2.ed. Brasília,1994. 50 p.

BRASIL. Agência Nacional de Vigilância Sanitária (ANVISA). Altera o texto do subitem 3 do item IV da Portaria 15 de 23 de agosto de 1988, que passa a ter a seguinte redação: “ desinfetantes para indústrias em superfícies onde se dá o preparo, consumo e estocagem dos gêneros alimentícios, podendo utilizar, exclusivamente, os princípios ativos dos grupos C, D, E, F e H do SUBANEXO 1 e também a substância PERÓXIDO DE HIDROGÊNIO". Resolução $\mathrm{n}^{\circ} 211$, de 18 de junho de 1999.

BRASIL. Agência Nacional de Vigilância Sanitária (ANVISA). Aprova NORMAS TÉCNICAS ESPECIAIS, do Estado de São Paulo, revistas pela CNNPA, relativas a alimentos (e bebidas), para efeito em todo território brasileiro. Resolução $n^{\circ} 12$ de 1978.

BRASIL. Agência Nacional de Vigilância Sanitária (ANVISA). Determina que o registro de produtos saneantes domissanitários com finalidade antimicrobiana seja procedido de acordo com as normas regulamentares. Portaria $\mathrm{n}^{\mathrm{o}}$ 15, de 23 de agosto de 1988.

BRASIL. Agência Nacional de Vigilância Sanitária (ANVISA). Indeferir o Pedido de Revalidação de Registro de Produto, de produtos farmacêuticos, conforme relação em anexo. Resolução Resolução no ${ }^{\circ}$ 1469, de 13 de setembro de 2001. 
CONRAD, R. N. Increasing in hand-alcohol consumption among medical staff in a general hospital as a result of introducing a training program and a visualization test. Infect. Control Hosp. Epidemiol., v.22, p.41-42, 2001.

DENTON, G. W. Chlorhexidine. In: BLOCK, S. S. (Ed.). Disinfection, sterilization, and preservation. 4. ed. Philadelphia: Lea \& Feabiger 1991. p.1504.

DIAZ, R.B.; VESSONI PENNA, T.C.; TAKEUTI, C.E.; TAIRA, E.T.; GUIMARÃES, T. Centralização do processo de desinfecção de materiais semi-críticos e não-críticos no Hospital Santa Cruz: melhoria da qualidade e redução de custos. Laes \& Haes, v.6, p.68-78, 2000.

GANDHI, P. A.; SAWANT, A. D.; WILSON, L., A.; AHEARN, D. G. Adaptation and growth of Serratia marcescens in contact lens disinfectant solutions containing chlorhexidine gluconate. Appl. Environ. Microbiol., v.59, p.183-188, 1993.

KENNETH, J. R. Sterilization, pasteurization and desinfection. In:_. Sherris Medical Microbiology: an introduction to infectious diseases. New York: Appleton and Lange, 1994. p.171-178.

KESSLER, M.; HUU, T. C.; MARIOT, A.; CHANLIAU, J. Hemodialysis associated complications due to sterilizing agents ethylene oxide and formaldehyde. Contrib. Nephrol., v.62, p.13-23, 1988.

MAZZOLA, P. G.; PENNA, T. C. V.; MARTINS, A. M. Determination of decimal reduction time (D value) of chemical agents used in hospitals for disinfection purposes. BMC Infec. Dis., v.3, p.24-34, 2003.

MAZZOLA, P.G.; VESSONI PENNA, T.C.; MACHOSHVILI, I.A.; ROGRIGUES, R. C. Eficácia dos Agentes Químicos no Programa de Limpeza, Desinfecção e Esterilização. Laes \& Haes, v.127, p.100-126, 2000.

McDOnNELL, G.; RUSSELL, A. D. Antiseptics and desinfectants: activity, action, and resistance. Clin. Microbiol. Rev., v.12, p.147-179, 1999.

PENNA, T. C. V.; MAZZOLA, P. G.; MARTINS, A. M. The efficacy of chemical agents in cleaning and disinfection programs. BMC Infec. Dis., v.1, p.16, 2001.

PENNA, T. C. V.; MACHOSHVILI, I. A.; TAQUEDA, M. E. $\mathrm{S}$. Bacillus stearothermophilus sporulation response to different composition media. PDA J. Pharm. Sci. Techn., v.52, p.198-208, 1998.
RUTALA, W. A. APIC guidelines for selection and use of disinfectants. Am. J. Infect. Control, v.23, p.313-342, 1995.

RUTALA, W. A. Disinfection, sterilization and antiseptics in health care. New York: Polyscience Publishers, 1998. 292 p.

RUTALA, W. A. Selection and use of disinfections in health care. In: _. Hospital epidemiology and infection control. Philadelphia: Mayhall, 1996. p.2060.

RUTALA, W. A.; WEBER, D. J. FDA labeling requirements for disinfection of endoscopes: a counterpoint. Infect. Control Hosp. Epidemiol., v.16, p.231-235, 1995.

RUTALA, W. A.; WEBER, D. J. Principles of disinfecting patient-care items. In: Disinfection, Sterilization and Antiseptics in Health Care. New York: Polyscience Publishers, 1998. p.133-149.

RUTALA, W. A.; WEBER, D. J. Registration of disinfectants based on relative microbicidal activity. Infect. Control. Hosp. Epidemiol., v.25, p.333-341, 2004.

SAGRIPANTI, J. L.; BONIFACINO, A. Effects of salt and serum on the sporocidal activity of liquid disinfectants. $J$. AOAC Intern., v.80, p.1198-1207, 1997.

SATTAR, S. A. Microbicidal testing of germicides: an update. In: RUTALA, W. A. (Ed.). Disinfection, sterilization and antiseptics in health care. New York: Polyscience Publishers 1998. p.227-240.

TRAUMANN, M. M.; MICHALSKY, T.; WIEDECK, H.; RADOSAVLJEVIC, V.; RUHNKE, M. Tap Water Colonization with Pseudomonas aeruginosa in a surgical intensive care unit (ICU) and relation to Pseudomonas infections of ICU patients. Infect. Control Hosp. Epidemiol., v.22, p.49-52, 2001.

TRUJILLO R.; LAIBLE N. Reversible inhibition of spore germination by alcohols. Appl. Microbiol., v.20, p.620$623,1970$.

VESSONI PENNA, T. C., SCHAFFNER, D., ABE, L. E., MACHOSHVILI, I. A. Inactivation of Brazilian wild type and enterotoxigenic Escherichia coli by chlorine. J. Ind. Microbiol., v.16, p.57-61, 1996.

Received for publication on $14^{\text {th }}$ july 2008 Accepted for publication on $24^{\text {th }}$ october 2008 